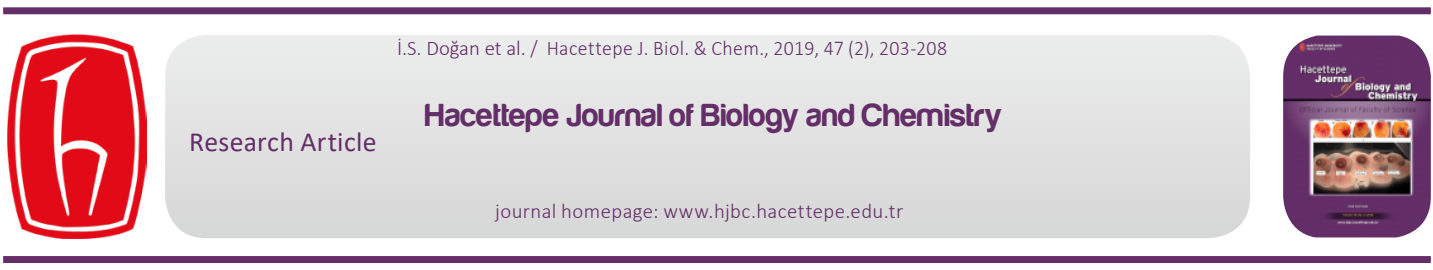

\title{
Investigation of Reaction of Some Ester Ethoxycarbonyl Hydrazones with 1-Adamantyl Amine
}

\section{Bazı Ester Etoksikarbonil Hidrazonların 1-Adamantil Amin ile Reaksiyonlarının Araştırılması}

\author{
İnci Selin Doğan ${ }^{1 \oplus}$, Hasan Erdinç Sellitepe ${ }^{1 \oplus}$, Bahittin Kahveci ${ }^{2}$ \\ 'Department of Pharmaceutical Chemistry, Faculty of Pharmacy, Karadeniz Technical University, Trabzon, Turkey. \\ ${ }^{2}$ Department of Nutrition and Dietetics, Faculty of Health Sciences, Karadeniz Technical University, Trabzon, Turkey.
}

\section{ABSTRACT}

$\mathrm{n}$ this study, the reactions of the 1-adamantyl amine with 4 different ester ethoxycarbonyl hydrazone derivatives were studied. At first, iminoester hydrochloride derivatives were synthesized according to the Pinner method. Then they were reacted with ethyl carbazate to synthesize ester ethoxycarbonyl hydrazone derivative compounds. In the last step, 3-substituted-4-adamantyl-1,2,4-triazol-5-one derivatives were aimed to synthesize, the ester ethoxycarbonyl hydrazone compounds were heated in an oil bath dry to dry with 1-adamantyl amine. It has been observed, however, that the ring is not closed according to IR and ${ }^{1} \mathrm{H}$-NMR analysis and the ethyl $\mathrm{N}$-(adamantylcarbamoyl)alkylcarbohydrazonoate derivative compounds were synthesized as stabile and original compounds. The structures of the synthesized compounds were elucidated by spectroscopic methods using IR, ${ }^{1} \mathrm{H}-\mathrm{NMR},{ }^{13} \mathrm{C}-\mathrm{NMR}$ spectra and LC/MS analysis.

\section{Key Words}

1-adamantyl amine, ester ethoxycarbonyl hydrazone, iminoester hydrochlorides, Pinner method.

\section{öz}

u çalışmada, 1-adamantil amin bileşiğinin 4 farklı ester etoksikarbonil hidrazon türevi ile reaksiyonu incelenmiştir. IIlk olarak, iminoester hidroklorür türevleri Pinner yöntemine göre sentezlendi. Daha sonra, ester etoksikarbonil hidrazon türevi bileşiklerinin sentezlenmesi için etil karbazat ile reaksiyona sokuldu. Son basamakta, 3-sübstitüe-4-adamantil-1,2,4triazol-5-on türevlerinin sentezlenmesi amaçlandı, ester etoksikarbonil hidrazin türevli bileşikler 1-adamantil amin ile bir yağ banyosunda kuru kuruya ısıtıldı. Ancak, IR ve ${ }^{1} \mathrm{H}-\mathrm{NMR}$ analizleri ile halkanın kapanmadığı anlaşıldı ve etil N- (adamantilkarbamoil)alkilkarbohidrazonoat türevi bileşiklerin stabil ve orijinal bileşikler olarak sentezlendiği gözlenmiştir. Sentezlenen bileşiklerin yapısı, IR, ${ }^{1} \mathrm{H}-\mathrm{NMR},{ }^{13} \mathrm{C}-\mathrm{NMR}$ spektrumları ve LC/MS analizi gibi spektroskopik yöntemlerle kanıtlandı.

\section{Anahtar Kelimeler}

1-adamantil amin, ester etoksikarbonil hidrazon, iminoester hidroklorürler, Pinner metot.

Article History: Received: Oct 18, 2018; Revised: Feb 14, 2019; Accepted: Feb 25, 2019; Available Online: Sep 15, 2019. DOI: $10.15671 / \mathrm{hjbc} .623792$

Correspondence to: I.S.Doğan, Department of Pharmaceutical Chemistry, Karadeniz Technical University, Trabzon, Turkey. E-Mail: isdogan@ktu.edu.tr 


\section{INTRODUCTION}

nvestigation and synthesis of new heterocyclic compounds are extremely important because it will contribute to the potency of the drug active substance [1]. The development of effective and alternative methods for the synthesis of compounds with potential biological properties has become more important, nowadays. The 1-adamantyl amine, which has been used in the synthesis of heterocyclic compounds since 1967, has been a highly studied substance due to the important pharmacological activities of its derivatives in the following years. Compounds carrying the adamantane ring are known for their antiviral activity $[2,3]$.

Several examples of compounds which contain adamantane ring and exhibit drug properties, such as tromantadine, rimantadine and adapromin, are given in Figure 1 [4-6].

In a study by Naik et al. in 2017, a radioligand was developed with 1-adamantyl amine for PET imaging [7]. In another study done in 2017, ferrocenylmethylidene and arylidene substituted adamantane ring based compounds as potential anticancer properties were synthesized [8]. In another study, biologically active adamantyl hybrid compounds were synthesized [9]. Recently, adamantyl derivative studies have been carried out with important biological properties such as cytotoxic, selective cannabinoid type 2 receptor agonists, interleukin inhibitor, antitubercular, photoswitchable receptor antagonist, antimicrobial and antitumor activities [1016]. Studies with some other biological properties have been carried out with adamantyl amine. With this wide spectrum of activities given in the literature, studies are continuing for adamantyl amine [17-22].

In this study, the reaction of adamantyl amine with ethoxycarbonylhydrazones was investigated for the first time. Ester ethoxycarbonylhydrazones have long been used in the synthesis of heterocyclic compounds containing the triazole ring. It is known that compounds carrying triazole ring have antibacterial, antifungal, antitumoral and antiepileptic activities [23,24].

In this work, the synthesis of triazole derivatives containing the adamantyl amine ring is aimed by the reaction of 1-adamantyl amine with ethoxycarbonylhydrazones. However, ethyl N-(adamantylcarbamoyl)alkylcarbohydrazonoate derivatives were obtained, although the expected ring closure was not achieved according to IR and $1 \mathrm{H}-\mathrm{NMR}$ spectral data. These obtained compounds are both stable and new compounds.

\section{MATERIALS and METHODS}

\section{Chemistry}

Synthesis pathway for the title compounds (3a-d) is shown in (Figure 2).

Compounds $1 \mathrm{a}-\mathrm{d}$, the iminoester hydrochloride derivatives, was synthesized by Pinner method $[25,26]$. Then compounds ( $1 a-d)$ reacted with ethyl carbazate to yield ester ethoxycarbonylhydrazone compounds (2a-d) $[23,24]$. The final compounds 3a-d were synthesized by the reaction of ester ethoxycarbonylhydrazone compounds (2a-d) with 1-adamantyl amine compound (Figure 2).

Their molecular structures and purity were confirmed by IR, 1H-NMR, 13C-NMR and LC/MS spectral data.

\section{Experimental}

The general synthesis of compounds 3a-d was summarized in (Figure 2). All reagents and solvents were obtained from commercial suppliers. All reactions were monitored by thin-layer chromatography (TLC) on silica gel pre-coated F254 Merck plates and the plates were

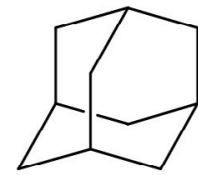

Adamantane

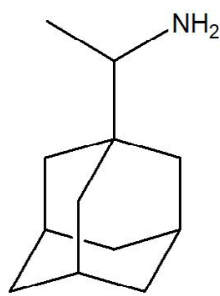

Rimantadine

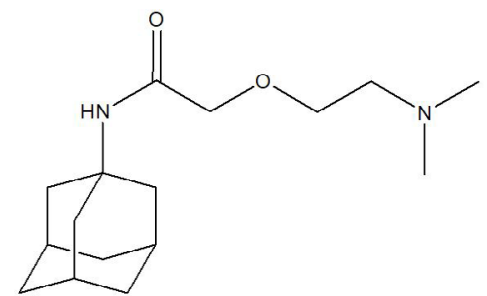

Tromantadine

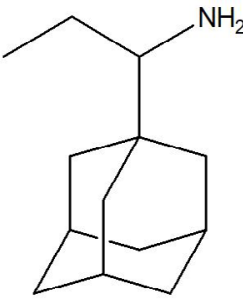

Adapromin

Figure 1. Structure of adamantane and adamantane derivative drugs. 


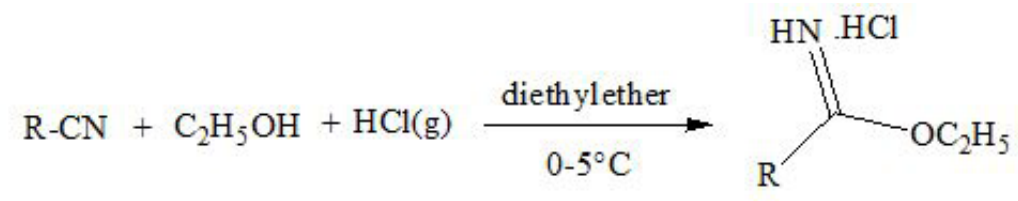

\section{Compounds la-d}

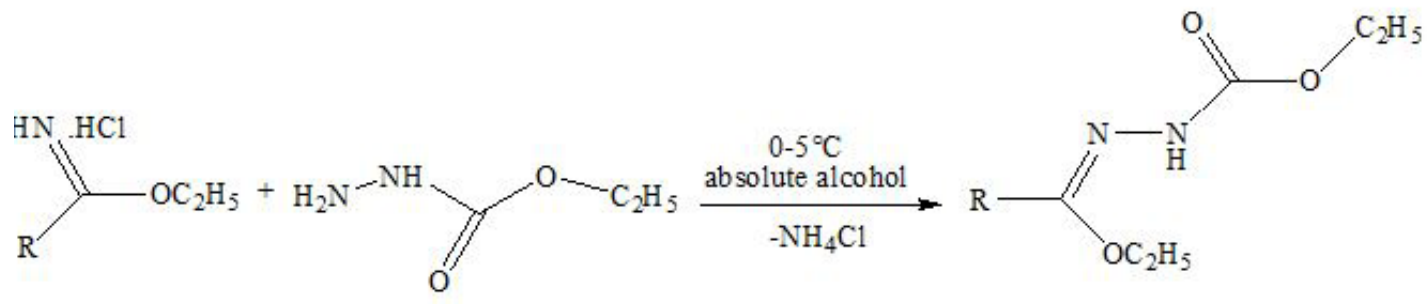

Compounds 2a-d<smiles>CCOC(=O)NN=C(C)OCC</smiles><smiles>NC12CC3CC(CC(C3)C1)C2</smiles><smiles>CCC[18OH]</smiles><smiles>[R]C(=NNC(=O)NC12CC3CC(CC(C3)C1)C2)OCC</smiles>

Compound 3a-d
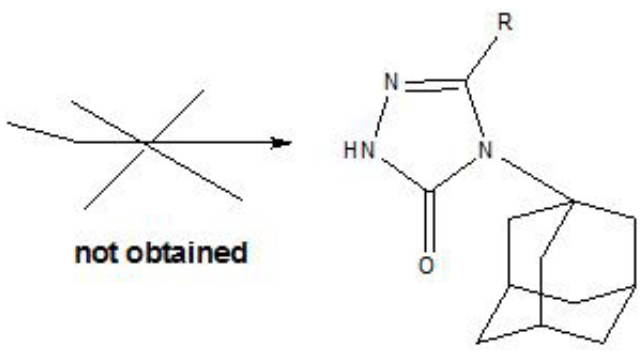

Figure 2. Synthesis of the Compounds 3a-d.

examined under $254 \mathrm{~nm}$ UV light. Melting points (mp) were recorded by Electrothermal Digital Melting Point Apparatus without correction. ${ }^{1} \mathrm{H}$ - and ${ }^{13} \mathrm{C}$-NMR spectrum was recorded on Varian Mercury $400,400 \mathrm{MHz}$ Digital FT-NMR instrument with tetramethylsilane as internal standard. Chemical shifts $(\delta)$ were expressed in parts per million (ppm). Significant ${ }^{1} \mathrm{H}-\mathrm{NMR}$ data are reported in the following order: multiplicity (s, singlet; $d$, doublet; dd, doublet of doublet; $t$, triplet; m, multiplet) and number of protons. IR spectra were recorded on Perkin Elmer Spectrum FT-IR spectrophotometer using attenuated total reflectance (ATR) FT-IR method. Mass spectrometry was conducted using Micromass ZQ LCMS spectrometer (ESI+ mode).

\section{Synthesis of Compounds}

1. General Procedure for the Synthesis of Iminoester Hydrochloride Derivatives (Compounds 1a-d)

Our initial compounds were synthesized by the Pinner method $[25,26]$. Absolute ethanol $(0.103 \mathrm{~mol})$ was added to nitrile derivatives $(0.101 \mathrm{~mol})$ solution in $15 \mathrm{~mL}$ anhydrous diethyl ether. The mixture was kept in the freezer for 12 hours, and precipitated by addition of anhydrous diethyl ether. Dry $\mathrm{HCl}$ gas was passed through the reaction mixture until saturation. The precipitated crude product was filtered, washed with anhydrous diethyl ether and dried over anhydrous $\mathrm{CaCl}_{2}$, and compounds (1a-d) were obtained $[23,24]$. 
2. General Procedure for the Synthesis of Ester EthoxyCarbonyl Hydrazone Derivatives (Compounds 2a-d)

The absolute ethanol solution of ethyl carbazate $(0.03$ mol) was added to the absolute ethanol solution of iminoester hydrochloride derivatives (1a-d) (0.03 mol). The mixture was stirred in the ice bath. The turbidity was observed with the precipitation of the $\mathrm{NH}_{4} \mathrm{Cl}$ and the reaction was terminated. The $\mathrm{NH}_{4} \mathrm{Cl}$ in the medium was then filtered. The mixture was kept in deep freezing for 12 hours. Then the solvent was evaporated in the rotary evaporator. Crystals formed after extraction with petroleum ether were filtered, washed with anhydrous diethyl ether and dried over $\mathrm{CaCl}_{2}[23,24]$.

\section{General Procedure for the Synthesis of Ethyl $\mathrm{N}$-(adamantylcarbamoyl)alkylcarbohydrazonoate Derivatives (Compounds 3a-d)}

Ester ethoxycarbonylhydrazone derivatives (2a-d, $0.005 \mathrm{~mol})$ and 1-adamantyl amine $(0.005 \mathrm{~mol})$ were made into a homogeneous powder mixture by means of a glass baguette and heated without solvent in the oil bath under reflux. The reaction progress was moni tored by TLC. The reaction continued for 2 hours. The resulting product was purified by crystallization with ethyl acetate and filtered to give a white powder. The product was obtained (Figure 2).

\section{Ethyl N-(adamantylcarbamoyl)ethylcarbohydrazono- ate (Compound 3a)}

General procedure was followed using ethyl ester ethoxycarbonylethylhydrazone and 1-adamantyl amine to give 3 a as a white solid (yield 57.8\%; mp 246-7?C). IR (ATR): $\tilde{v}=3343(\mathrm{~N}-\mathrm{H}), 2902,2847$ (C-H, aliphatic), 1622 $(\mathrm{C}=\mathrm{O}), 1553(\mathrm{~N}-\mathrm{H}), 1450(\mathrm{C}=\mathrm{N})$, 1356, 1342, 1294 (C-N). 1H-NMR (400 MHz, DMSO-d6) $\delta 0.99(3 \mathrm{H} ; \mathrm{t}$; - $\mathrm{CH} 2 \mathrm{CH} 3)$, 1.20 (3H; t; - $\mathrm{OCH} 2 \mathrm{CH} 3), 1.56-2.33(15 \mathrm{H} ; \mathrm{m}$; adamantyl $\mathrm{H}), 3.92(2 \mathrm{H} ; \mathrm{q} ;-\mathrm{CH} 2 \mathrm{CH} 3), 4.02\left(2 \mathrm{H} ; \mathrm{q} ;-\mathrm{OCH}_{2} \mathrm{CH} 3\right), 5.73$ $\left(1 \mathrm{H} ; \mathrm{s} ; \mathrm{N}_{1}-\mathrm{H}\right)$ and $8.39 \mathrm{ppm}(1 \mathrm{H} ; \mathrm{s} ; \mathrm{N} 2-\mathrm{H}) .13 \mathrm{C}-\mathrm{NMR}$ (DMSO-d6, 400 MHz) $\delta 9.37$ (1C;-CH2CH3), 10.52 (1C; $\mathrm{OCH} 2 \mathrm{CH} 3), 14.54$ (1C;- $\mathrm{CH} 2 \mathrm{CH} 3), 15.52,21.23,22.16$, 29.39, 36.63, 42.22, 49.89, 61.43 (10C; adamantyl-CH2-), 63.53 (1C;-OCH2CH3), 149.98 (1C;-C=N-) and 157.47 ppm (1C;-NHCONH-). LC-MS (ESI+) m/z: 293.4 (M+, base peak, 100\%).

\section{Ethyl N-(adamantylcarbamoyl)phenylcarbohydrazo- noate (Compound 3b)}

General procedure was followed using ethyl ester ethoxycarbonylphenylhydrazone and 1-adamantyl amine to give $3 \mathrm{~b}$ as a white solid (yield $52.6 \%$; $\mathrm{mp} 256-8^{\circ} \mathrm{C}$ ). IR
(ATR): $\tilde{v}=3387(\mathrm{~N}-\mathrm{H}), 2902,2849$ (C-H, aliphatic), 1663 $(\mathrm{C}=\mathrm{O}), 1622(\mathrm{~N}-\mathrm{H}), 1516,1452(\mathrm{C}=\mathrm{C}$ and $\mathrm{C}=\mathrm{N}), 1331$, 1094, 1065 (C-N) ve 750 (monosubstitue benzene de-

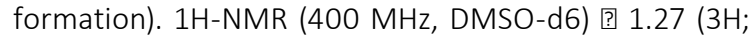
t; - $\mathrm{CH} 2 \mathrm{CH} 3), 1.63-2.03(15 \mathrm{H} ; \mathrm{m}$; adamantyl H), 3.94 $\left(2 \mathrm{H} ; \mathrm{q} ;-\mathrm{OCH}_{2} \mathrm{CH} 3\right), 6.14\left(1 \mathrm{H} ; \mathrm{s} ; \mathrm{N}_{1}-\mathrm{H}\right), 7.42-7.59(5 \mathrm{H} ; \mathrm{m}$; phenyl protons) and $9.11 \mathrm{ppm}(1 \mathrm{H} ; \mathrm{s} ; \mathrm{N2}-\mathrm{H}) .13 \mathrm{C}-\mathrm{NMR}$ (DMSO-d6, $400 \mathrm{MHz}$ ) $\delta 15.45$ (1C;-OCH2CH3), 29.54, $36.48,36.64,38.77,39.37,39.58,42.13,42.19,42.51$, 50.27 (10C; adamantyl-CH2-), 66.38 (1C;-OCH2CH3), $127.29,128.42,129.10,130.02,131.45$ (6C; phenyl-CH2-) 146.71 (1C;-C=N-) and 153.98 ppm (1C;-NHCONH-). LCMS (ESI+) m/z: 341.45 (M+, base peak, 100\%).

\section{Ethyl N-(adamantylcarbamoyl)benzylcarbohydrazo- noate (Compound 3c)}

General procedure was followed using ethyl ester ethoxycarbonylbenzylhydrazone and 1-adamantyl amine to give $3 c$ as a white solid (yield 47.3\%; mp 249-50?C). IR (ATR): $\tilde{v}=3342(\mathrm{~N}-\mathrm{H}), 2902,2847$ (C-H, aliphatic), 1622 (C=O), $1553(\mathrm{~N}-\mathrm{H}), 1450$ (C=N), 1356, 1342, 1294 (C-N). 1H-NMR (400 MHz, DMSO-d6) ? $1.25(3 \mathrm{H} ; \mathrm{t}$; $-\mathrm{CH} 2 \mathrm{CH} 3), 1.53-1.94(15 \mathrm{H} ; \mathrm{m}$; adamantyl H), $3.91(2 \mathrm{H}$; q; $\left.-\mathrm{OCH}_{2} \mathrm{CH} 3\right), 5.32(2 \mathrm{H} ; \mathrm{s} ;-\mathrm{CH} 2-\mathrm{C} 6 \mathrm{H} 5), 6.11(1 \mathrm{H} ; \mathrm{s}$; $\left.\mathrm{N}_{1}-\mathrm{H}\right)$, 7.41-7.60 (5H; m; phenyl protons) and $9.11 \mathrm{ppm}$ (1H; s; N2-H). 13C-NMR (DMSO-d6, $400 \mathrm{MHz}) \delta 15.52$ (1C;-OCH2CH3), 29.37, 36.46, 36.63, 42.11, 42.48, 49.68, 50.25 (11C; - $\mathrm{CH} 2$-phenyl and adamantyl-CH2-), 66.37 (1C;-OCH2CH3), 127.27, 129.08, 129.10, 130.00, 131.43 (6C; phenyl-CH2-) 146.69 (1C;-C=N-) and 153.97 ppm (1C;-NHCONH-). LC-MS (ESI+) m/z: 355.48 (M+, base peak, 100\%).

\section{Ethyl N-(adamantylcarbamoyl) p-chlorobenzylcarbohydrazonoate (Compound 3d)} General procedure was followed using Ethyl ester ethoxycarbonyl p-chlorobenzylhydrazone and 1-adamantyl amine to give $3 \mathrm{~d}$ as a white solid (yield 55.2\%; mp 303-5?C). IR (ATR): $\tilde{v}=3345(\mathrm{~N}-\mathrm{H}), 2905,2847$ (C-H, aliphatic), 1622 ( $\mathrm{C}=\mathrm{O}), 1553(\mathrm{~N}-\mathrm{H}), 1516,1450(\mathrm{C}=\mathrm{C}$ and $\mathrm{C}=\mathrm{N})$, 1356, 1342, 1279, 1234 (C-N) ve 817-750 (disubstitue benzene deformation). 1H-NMR (400 MHz,DMSO-d6) ? 1.125 (3H; t; - $\mathrm{CH} 2 \mathrm{CH} 3), 1.56-1.95$ (15H; m; adamantyl H), $3.96\left(2 \mathrm{H} ; \mathrm{q} ;-\mathrm{OCH}_{2} \mathrm{CH} 3\right), 5.32(2 \mathrm{H}, \mathrm{s} ;-\mathrm{CH} 2-\mathrm{C} 6 \mathrm{H} 4 \mathrm{Cl}), 5.76$ $\left(1 \mathrm{H} ; \mathrm{s} ; \mathrm{N}_{1}-\mathrm{H}\right), 7.20-7.36(4 \mathrm{H} ; \mathrm{m}$; phenyl protons) and 8.70 ppm (1H; s; N2-H). 13C-NMR (DMSO-d6, $400 \mathrm{MHz}) \delta$ 14.47 (1C;-OCH2CH3), 29.35, 33.26, 36.44, 36.62, 42.20, 42.49, 49.95 (11C; - $\mathrm{CH} 2-$ phenyl and adamantyl-CH2-), 61.85 (1C;-OCH2CH3), 128.80, 130.94, 131.65, 134.77 
(6C; phenyl-CH2-) 146.69 (1C;-C=N-) and 155.70 ppm (1C;-NHCONH-). LC-MS (ESI+) m/z: $401.2(\mathrm{M}+2), 389.92$ $(\mathrm{M}+$, base peak, 100\%).

\section{RESULTS and DISCUSSION}

In this study, we have synthesize series of ethyl $\mathrm{N}$-(adamantylcarbamoyl)alkylcarbohydrazonoate derivatives by the reaction of various ester ethoxycarbonylhydrazone compounds with 1-adamantyl amine.

In this work, the synthesis of 3-substituted-4-adamantyl4,5-dihydro-1H-1,2,4-triazol-5-one derivatives was aimed. However, it was observed that this ring closure reaction did not occur at high temperature due to the steric effect. 4 novel ethyl $\mathrm{N}$-(adamantylcarbamoyl) alkylcarbohydrazonate derivatives (compounds 3a-d) were obtained.

The ethoxycarbonylhydrazones compounds are the most commonly used in closing the triazole ring. In this study, according to the $1 \mathrm{H}-\mathrm{NMR}$ spectrum of the phenyl substituted derivative (compound $4 \mathrm{~b}$ was prepared while the compound $3 \mathrm{~b}$ was obtained), it was observed that the triazole ring was not closed. If the triazole ring was closed, the peaks of the $-\mathrm{CH}_{2}-\mathrm{CH}_{3}$ group had to disappear. When the reaction was carried out in the oil bath, the reaction did not give the expected triazole-3one compounds due to the steric effect and the sublimation property of the adamantyl amine. The absence of the triazole ring in the reaction of the adamantyl amine with ethoxycarbonylhydrazones, even if the ethanol solvent was used, indicated that the main effect in this reaction was the steric hindrance.

The reaction was resolved in $10 \mathrm{ml}$ of diethylene glycol dimethyl ether solvent and repeated at high temperature. As the reaction had to be run at a higher temperature, we selected diethylene glycol dimethyl ether solvent with a high boiling point $\left(162^{\circ} \mathrm{C}\right)$. When ethanol was used, the reaction went the same way, but the reaction needed to increase the ambient temperature, so we choose this solvent. And when the result was a single spot on TLC; it has been observed that these products are original, the work was returned to this method.

Spectral (IR, $\left.{ }^{1} \mathrm{H}-\mathrm{NMR},{ }^{13} \mathrm{C}-\mathrm{NMR}\right)$ data of the synthesized compounds (3a-d) were consistent with the literature rules [27-31]. The findings obtained from the mass spectra of compounds which we have synthesized confirm the structures of the compounds. In the mass spectrum of compound $3 \mathrm{~d}$ which has chlorine atoms on phenyl ring, $\mathrm{M}+2$ peak was observed.

\section{CONCLUSION}

In this study, a ring closure reaction of 1-adamantyl amine with ester ethoxycarbonylhydrazone was carried out to synthesize a series of triazole derivatives of adamantyl amine. However, the expected ring closure at the end of the study did not occur, also the reaction carried out at high temperature in the oil bath by dry to dry. Instead, an open chain derivative of the ethoxycarbonyl hydrazone of 1-adamantyl amine was obtained. The probable cause of not to happen ring closure at high temperature is the steric effect of the adamantyl group. As a result, four new ethyl $\mathrm{N}$-(adamantylcarbamoyl) alkylcarbohydrazonate derivative compounds (3a-d) were obtained. The relationship between the structure and the biological activity of the compounds will be concluded after their biological activity screening tests. These results will be used to design new active compounds of related with this group in future.

\section{Acknowledgments}

This study has been supported by Tübitak 2209A Project No. 1919B011603783 Support Program for Domestic Research Projects of University Students.

\section{References}

1. J. Warren, Drug discovery: lessons from evolution, Br. J. Clin. Pharmacol., 71 (2011) 497-503.

2. H.U. Daeniker, 1-Hydrazinoadamantan, Helvetica Chimica Acta., 50 (1967) 2008-2010.

3. T.L. Thomas, M. Fedorchuk, B.V. Shetty, F.E. Anderson, Synthesis and activity of some 3-substituted 1,2,3,4-pseudooxatriazol-5-ones and their precursors and related compounds, J. Med. Chem., 13 (1970) 196-203.

4. M.G. Alves Galvão, M.A. Rocha Crispino Santos, A.J. Alves da Cunha, Amantadine and rimantadine for influenza $A$ in children and the elderly, Cochrane Database Syst Rev., 21 (2014) CD002745.

5. K. Spilovska, F. Zemek, J. Korabecny, E. Nepovimova, O. Soukup, M. Windisch, K. Kuca, Adamantane - A lead structure for drugs in clinical practice, Curr. Med. Chem., 23 (2016) 3245-3266.

6. S.V. Krapivin, S.A. Sergeeva, I.S. Morozov, Comparative analysis of the effects of adapromine, midantane, and bromantane on bioelectrical activity of rat brain, Bull. Exp. Biol. Med. 125 (1998) 175-179.

7. R. Naik, H. Valentine, A. Hall, W.B. Mathews, J.C. Harris, C.S. Carter, R.F. Dannals, D.F. Wong, A.G. Horti, Development of a radioligand for imaging $\mathrm{V} 1 \mathrm{a}$ vasopressin receptors with PET, Eur. J. Med. Chem., 139 (2017) 644-656. 
8. M. Kamenova-Nacheva, M. Schröder, E Pasheva, I. Slavchev, V Dimitrov, G. Momekov, R. Nikolova, B. Shivachev, I. Ugrinova, G.M. Dobrikov, Synthesis of ferrocenylmethylidene and arylidene substituted camphane based compounds as potential anticancer agents, New J. Chem., 41 (2017) 91039112.

9. U. Kalita, S. Kaping, R. Nongkynrih, I. Boiss, L. Indira Singha, J. Narain Vishwakarma, Design, synthesis, structure elucidation, and biological activities of 3-(substituted amino)-1-(pyridin-4-yl)propenones and 5-isonicotinoyl1,2,3,4-tetrahydropyrimidine-adamantane hybrids, Monatshefte für Chemie., 148 (2017) 2155-2171.

10. A.N. Balaev, V.N. Osipov, K.A. Okhmanovich, E.A. Ruchko, M.A. Baryshnikova, D.S. Khachatryan, Pentapeptide analogs of somatostatin containing a thiazolidine fragment: synthesis and cytotoxic activity, Russian Chemical Bulletin., 65 (2016) 2948-2951.

11. Y. Shi, Y.H. Duan, Y.Y. Ji, Z.L. Wang, Y.R. Wu, H. Gunosewoyo, X.Y. Xie, J.Z. Chen, F. Yang, J. Li, J. Tang, X. Xie, L.F. Yu Amidoalkylindoles as potent and selective cannabinoid type 2 receptor agonists with in vivo efficacy in a mouse model of multiple sclerosis, J. Med. Chem., 60 (2017) 7067-7083.

12. A. Quéméner, M. Maillasson, L. Arzel, B. Sicard, R. Vomiandry, E. Mortier, D. Dubreuil, Y. Jacques, J. Lebreton, M. MathéAllainmat, Discovery of a small-molecule inhibitor of interleukin 15: Pharmacophore-based virtual screening and hit optimization, J. Med. Chem., 60 (2017) 6249-6272.

13. E. Azzali, D. Machado, A. Kaushik, F. Vacondio, S. Flisi, C.S. Cabassi, G. Lamichhane, M. Viveiros, G. Costantino, M. Pieroni, Substituted N-phenyl-5-(2-(phenylamino)thiazol4-yl)isoxazole-3-carboxamides are valuable antitubercular candidates that evade innate efflux machinery, J. Med. Chem., 60 (2017) 7108-7122.

14. F.W.W. Hartrampf, D.M. Barber, K. Gottschling, P. Leippe, M. Hollmann, D. Trauner, Development of a photoswitchable antagonist of NMDA receptors, Tetrahedron, 73 (2017) 4905-4912

15. L.H. Al-Wahaibi, H.M. Hassan, A.M. Abo-Kamar, H.A. Ghabbour, A.A. El-Emam, Adamantane-isothiourea hybrid derivatives: synthesis, characterization, in vitro antimicrobial, and in vivo hypoglycemic activities, Molecules, 22 (2017) 710.

16. M. Xiaodong, F.Z. Shenging, US Patent 2017. CN106432104A.

17. A.P. Kozikowski, O.K. Onajole, J. Stec, C. Dupont, A. Viljoen, M. Richard, T. Chaira, S. Lun, W. Bishai, V.S. Raj, D. Ordway, L. Kremer, Targeting mycolic acid transport by indole2-carboxamides for the treatment of mycobacterium abscessus infections, J. Med. Chem., 60 (2017) 5876-5888.
18. R.P. Moldovan, K. Hausmann, W. Deuther-Conrad, P. Brust, Development of highly affine and selective fluorinated cannabinoid type 2 receptor ligands, ACS Med. Chem. Lett., 8 (2017) 566-571.

19. P.F. Zhao, Z.Q. Liu, 2-Isocyano glucose used in Ugi fourcomponent reaction: An approach to enhance inhibitory effect against DNA oxidation, Eur. J. Med. Chem., 135 (2017) 458-466.

20. N. Karalı, A. Akdemir, F. Göktaş, P. Eraslan Elma, A. Angeli, M. Kızılırmak, C.T. Supuran, Novel sulfonamide-containing 2-indolinones that selectively inhibit tumor-associated alpha carbonic anhydrases, Bioorg. Med. Chem., 25 (2017) 3714-3718.

21. J. Jimenez, I. Chakraborty, A.M. Del Cid, P.K. Mascharak, Five- and six-coordinated silver(i) complexes derived from 2,6-(pyridyl)iminodiadamantanes: sustained release of bioactive silver toward bacterial eradication, Inorg. Chem., 56 (2017) 4784-4787.

22. Y. Hu, Y. Wang, F. Li, C. Ma, J. Wang, Design and expeditious synthesis of organosilanes as potent antivirals targeting multidrug-resistant influenza A viruses, Eur. J. Med. Chem., 135 (2017) 70-76.

23. A. İkizler, N. Demirbaş, A. Demirbaş, A.A. İkizler, A convenient synthesis of 4-amino 3,5-dialkyl-4H-1,2,4-triazoles, Polish J. Chem., 70 (1996) 1114-1120.

24. B. Kahveci, Synthesis of 4-amino-4,5-dihydro-1H-1,2,4triazole-5-ones and their isatin-3-imine derivatives, Molecules,10 (2005) 376-382

25. A. Pinner, F. Klein, Umwandlung der Nitrile in Imide, Berichte der deutschenchemischen Gesellschaft, 10 (1877) 18891897

26. 26. R. Roger, D.G. Neilson, The chemistry of imidates, Chem. Rev., 61 (1961) 179-211.

27. P. Sykes, A Guidebook to Mechanism in Organic Chemistry, John Wiley\&Sons, New York, 1977.

28. R.W. Layer, The chemistry of imines, Chem. Rev. 63 (1963) 489-510.

29. R.M. Silverstein, Spectrometric identification of organic compounds, John Wiley\&Sons, New York,1998.

30. E. Pretsch, T. Clerk, J. Seibl, W. Simon, Tables of spectral data for structure determination of organic compounds, Springer-Verlag, Berlin, 1983.

31. S.D. Zurabishvili, T.J. Bukia, M.O. Lomidze, M.V. Trapaidze, E.N. Elizbarashvili, S.A. Samsoniya, T.V. Doroshenko, U. Kazmaier, Preparation of 2-(1-adamantyl)-1H-benzimidazole and novel derivatives thereof, Chem. Heterocyclic Comp., 51 (2015) 139-145. 